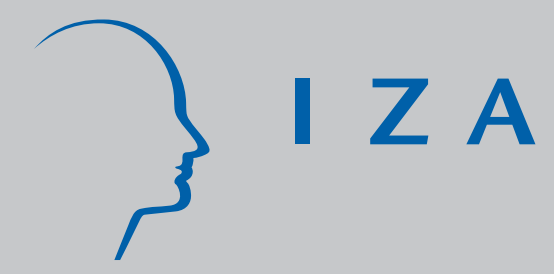

IZA DP No. 3223

Revolution and Family in Rural China: Influence of Family Background on Current Family Wealth

Hiroshi Sato

Li Shi

December 2007 


\title{
Revolution and Family in Rural China: Influence of Family Background on Current Family Wealth
}

\author{
Hiroshi Sato \\ Hitotsubashi University \\ Li Shi \\ Beijing Normal University \\ and IZA \\ Discussion Paper No. 3223 \\ December 2007 \\ IZA \\ P.O. Box 7240 \\ 53072 Bonn \\ Germany \\ Phone: +49-228-3894-0 \\ Fax: +49-228-3894-180 \\ E-mail: iza@iza.org
}

\begin{abstract}
Any opinions expressed here are those of the author(s) and not those of the institute. Research disseminated by IZA may include views on policy, but the institute itself takes no institutional policy positions.
\end{abstract}

The Institute for the Study of Labor (IZA) in Bonn is a local and virtual international research center and a place of communication between science, politics and business. IZA is an independent nonprofit company supported by Deutsche Post World Net. The center is associated with the University of Bonn and offers a stimulating research environment through its research networks, research support, and visitors and doctoral programs. IZA engages in (i) original and internationally competitive research in all fields of labor economics, (ii) development of policy concepts, and (iii) dissemination of research results and concepts to the interested public.

IZA Discussion Papers often represent preliminary work and are circulated to encourage discussion. Citation of such a paper should account for its provisional character. A revised version may be available directly from the author. 


\begin{abstract}

\section{Revolution and Family in Rural China: Influence of Family Background on Current Family Wealth}

This paper examines the influence of family human capital on offspring's economic status in post reform rural China by concentrating on the father-son relationship. We focus on two indicators of family background: family class origin (jiating chengfen) and occupational experience. The results of a family wealth function for 2002 suggest that, after controlling for other individual and family characteristics, both measures of family background have a significant influence on family wealth. First, parental experience of a nonagricultural family business before collectivization has a positive and statistically significant effect on current family wealth. Second, the offspring of landlord/rich peasant and middle peasant families are more likely to have higher family wealth than poor and lower-middle peasant families. We also find cohort and regional differences in the influence of family background. Our findings suggest that the strength and robustness of the Chinese rural family as a cultural institution preserves family human capital across radical institutional changes.
\end{abstract}

JEL Classification: $\quad$ D31, J24, N35, O15

Keywords: family human capital, family background, intergenerational correlation, distribution of wealth

Corresponding author:

Hiroshi Sato

Graduate School of Economics

Hitotsubashi University

2-1 Naka, Kunitachi

Tokyo 186-8601

Japan

E-mail: satohrs@econ.hit-u.ac.jp

\footnotetext{
* We are grateful for helpful comments from Professor John Knight, Department of Economics, Oxford University and Dr. Luo Chuliang, Beijing Normal University and the Institute of Economics, Chinese Academy of Social Sciences on the earlier versions of this paper. We gratefully acknowledge financial support for the survey provided mainly by the Ford Foundation, the Swedish International Development Cooperation Agency (SIDA) and partly by the Japan Society for Promoting Sciences (JSPS, Grant no. 18203018).
} 


\section{Summary}

\section{Objective}

This paper examines the influence of family human capital on offspring's wealth in contemporary rural China, concentrating on the father-son relationship. Family human capital is defined as the quality of intergenerational interactions focusing on education, skill formation, and attitudes toward socioeconomic advancement. As operational measures, we focus on two indicators of family background: family class origin (jiating chengfen) and occupational experience.

\section{Design and subjects}

Design: Cross-sectional study using a nationally representative survey of rural households in China (2002 CHIP survey).

Subjects: Families with male heads of household who are mature adults (aged 35-59 years) in 2002 (6,339 observations in the set of working data). Subjects are divided into two birth cohorts according to their historical situation.

(a) Early-reform cohort: Male household heads born 1943-1954 who reached mature adult status during the early stage of economic reform (1980s).

(b) Late-reform cohort: Male household heads born 1955-1967 who reached mature adult status during the latest stage of economic reform (after the 1990s).

\section{Outcome measure and estimation method}

Outcome measure: Log of per capita family wealth in 2002 (financial assets, durable goods, housing assets, and fixed assets for production).

Focal explanatory variables: (1) Parental years of schooling, (2) Parental Communist Party membership, (3) Parents' experience with nonagricultural family business before collectivization (i.e., up to 1957), (4) Family class origin: Landlord/rich peasant; middle peasant; poor and lower-middle peasant.

Estimation method: OLS regression with interaction terms for family human capital and birth cohort, family human capital and level of regional income.

\section{Estimation results}

(1) Parental education and political attainment: Insignificant, implying the importance of family human capital cannot be measured by formalistic indicators of parental human capital.

(2) Family business experience before collectivization: Positive and significant main effect and negative and significant interaction effect with GDP per capita at the county level, suggesting that the effect decreases with the level of regional economic development.

(3) Family class origin: Positive and statistically significant influence of landlord/rich peasant origin and middle peasant origin compared with poor and lower-middle peasant origin. Large and significant positive main effect of landlord/rich peasant origin on family wealth 
is cancelled out by the negative interaction effect with the early-reform cohort. By contrast, the interaction term for middle peasant origin and the early-reform cohort is not statistically significant. The sociopolitical environment and stage of economic reform can explain this cohort difference when male heads of household were in their adolescence and early adulthood.

\section{Conclusion}

Although radical institutional transformations after 1949 thoroughly destroyed the physical capital stocks of well-off families, invisible family human capital was preserved throughout the Maoist era and has again begun to play a role following the revival of the family as the basic unit of economic activity. This represents the robustness of Chinese rural families as a cultural institution. With reference to comparative economic transition, especially in Eastern Europe (i.e., Szelényi 1988), our findings share the view that in rural areas of transition economies, peasant entrepreneurship inherited from the pre-Revolutionary era plays an important role in the early stages of market transition. 


\section{Introduction}

This paper examines the influence of family human capital on offspring's economic status in post reform (after the 1980s) rural China by concentrating on the father-son correlation. Focus is on two indicators of family background: parent's experience of nonagricultural family business before collectivization and family class origin (jiating chengfen). Our empirical results suggest that both indicators significantly influence family wealth in 2002 . This indicates the strength and robustness of the Chinese rural family as a cultural institution that preserves and transmits human capital across radical institutional changes.

The data source for this paper is a nationally representative cross-sectional survey of Chinese rural households conducted in the spring of 2003 by the Chinese Household Income Project (CHIP) under the auspices of the Chinese Academy of Social Sciences. The reference year is 2002 (hereafter referred to as the 2002 CHIP survey). ${ }^{1}$ The survey covers 9,200 rural households distributed across 122 counties in 22 provincial-level administrative units: Beijing, Hebei, Shanxi, Liaoning, Jilin, Jiangsu, Zhejiang, Anhui, Jiangxi, Shandong, Henan, Hubei, Hunan, Guangdong, Guangxi, Chongqing, Sichuan, Guizhou, Yunnan, Shaanxi, Gansu, and Xinjiang. The sampling frame for the survey is a sub sample of the official rural household survey conducted by the National Bureau of Statistics (NBS).

Outside the direct transfer of wealth through inheritance, common explanations for the intergenerational transmission of economic status focus on the transmission of human capital across generations. That is, well-off families can invest more in their children's education, and well-educated children are more likely to achieve higher economic status. Another complementary trait is that wealthy families usually have a richer stock of human capital at the family level that directly and indirectly affects their children’s human capital formation. ${ }^{2}$ It is interesting to investigate the degree the transmission paths of socioeconomic status are relevant in transition economies: those that have experienced the establishment and collapse 
of the socialist system within a few generations. We intend to investigate this issue in the context of rural China from before 1949 to the beginning of the 2000s.

In our previous paper, Sato and Li (2007), we concentrated on the intergenerational correlation of education. We found that the offspring of landlord/rich peasant families who received education after the 1980s were more likely to achieve higher educational attainment than formerly poor and lower-middle peasant families, even though their parental education, family wealth, and other family characteristics were identical. We argue that the unique determinant of the intergenerational transmission of education in the post reform era is an education-oriented family culture, created as an intergenerational cultural rebound against the class-based social discrimination of the Maoist era (1950s-1970s).

The present paper is a continuation to Sato and $\mathrm{Li}$ (2007) and proceeds to an investigation of the intergenerational determinants of offspring's family wealth by employing class origin as a comprehensive proxy for family human capital. Our basic working hypotheses are as follows. First, in a rural setting, family human capital transmitted over generations, as well as formal education, plays a critical role as a determinant of offspring's economic outcomes. Second, the socialist revolution could not destroy family human capital stock in well-off families, although their physical capital was thoroughly destroyed by land reforms and the collectivization of agriculture. Third, family human capital stocks preserved throughout the Maoist era again play a role following the revival of the family as the basic unit of economic activities in the post reform era. To examine these hypotheses, we estimate the family wealth function by employing family class origin and other measures of family human capital: namely, parental education, parental political attainment, and parents’ nonagricultural family business experience before collectivization.

The previous literature on the intergenerational correlation of socioeconomic status in modern and contemporary China concentrates on education, official position, marriage, and 
fertility (see, for example, Campbell and Lee 2003, 2006; Deng and Treiman 1997; Ting 2004). We believe the current analysis is the first attempt to investigate the intergenerational correlation between family class origin and offspring's economic status in a nationwide context.

The paper is structured as follows. In Section 2, we discuss the framework of the study. Section 3 surveys the association between the family’s class origin and parental and offspring human capital. Section 4 estimates the family wealth function employing indicators of family human capital. Section 5 presents our conclusions and their research implications.

\section{Framework of research}

\section{Family human capital}

The subjects of this paper are families with male heads of household who are mature adults in 2002. Mature adults are defined here as those between the ages of 35 and 59 years in 2002. We consider the intergenerational transmission of family human capital between the current male heads of household and their parents. The reason we exclude households with younger heads of household is that they are likely to be in a transition stage to a stable family, and therefore their current economic outcomes may not be proper proxies for the economic status of the family over a longer time span. Similarly, heads of household over 60 years of age will not be representative. The previous literature, including Harding et al. (2005), defines mature adults as those aged 30-59 years. Considering that rural China has been experiencing dynamic changes in the economic environment, we set a narrower age range for mature adults. Thus, the working data set for our empirical analysis contains 6,660 households clustered into 122 counties distributed across 22 provincial-level administrative units.

The outcome measure is the family's current economic status. It is difficult to measure the family’s economic status properly based on a cross-section of data. Although a year of 
income can be misleading because of year-to-year fluctuations, a panel data set that can represent the steady stream of family income over a longer period is not available. In the following empirical study, we employ current family wealth as the proxy for the long-term stream of family income (per capita amount of financial assets, durable goods, housing assets, fixed productive assets, and other family assets in 2002).

The focal explanatory factor is family human capital. We firstly define family as an economic unit that makes an investment in the physical and human capital of its members, and secondly, as a cultural institution that promotes the socialization of children and the building up of their human capital. Offspring's human capital formation is considered to be affected by the level of family human capital. We conceptualize family human capital as the quality of intergenerational interactions focusing on education, skill formation, and attitudes toward socioeconomic advancement. Transmission of occupational and other socioeconomic experiences are also included.

Although its significance is broadly appreciated, it is not easy to find appropriate operational measures of family human capital. One common operational measure of family human capital is parental education. On the assumption that higher parental educational level could improve the quality of intra-family interaction, we employ years of schooling completed by the fathers of the current male heads of household. ${ }^{3}$ In addition, and in the context of rural China, parental political attainment should also be considered as an indicator of family human capital. Specifically, we introduce Communist Party membership of the fathers of male heads of household.

\section{Family background}

Because family human capital is a highly complicated concept, the above-mentioned indicators of parental status may not fully reflect the overall level of family human capital 
stock. Our suggestion is to add the following two indicators of family background as more comprehensive proxies for the overall level of family human capital.

The first indicator is parent's experience of nonagricultural family business before collectivization. Rural China experienced the establishment and collapse of the collective agricultural system between the late 1950s and the early 1980s with nonagricultural family business stalled for two decades. ${ }^{4}$ Considering this situation, parental occupational experiences before collectivization could be an important factor of family human capital that may affect a family’s economic activities following decollectivization. Specifically, we employ a dummy variable that indicates whether the parents' generation had any experience with nonagricultural family business before collectivization. ${ }^{5}$

The second indicator is family class origin. Family class origin was designated during the land reform period (late 1940s to early 1950s) based on economic status (mainly land holdings) before the land reform: this remained unchanged until the end of the 1970s. Figure 1 illustrates a conceptual framework of family class origin in the sociopolitical and economic hierarchy in rural China. The upper part of the figure addresses the sociopolitical hierarchy, while the lower half of the figure describes the economic hierarchy. The economic and sociopolitical hierarchy in the pre-1949 era is depicted as a pyramid. Families labeled as landlord/rich peasant — the minority—were at the top rung of both the economic and sociopolitical hierarchies. Middle peasant families were at the middle level, and poor and lower-middle peasant families—-the majority—were at the bottom of the structure (see the left-hand side of the figure). During the land reforms, the land and other property of landlord/rich peasant families were forfeited, and redistributed to families categorized as poor and lower-middle peasant. Landlord/rich peasant families were allowed to keep minimum means of production after the land reform. The properties of families designated as middle peasant were basically protected (see the trapezoid in the lower-middle part of the figure). 
After the thorough collectivization of agriculture in the late 1950s, all families had become economically homogeneous within the unit of collective agricultural production (the production team and the production brigade) under the People's commune system, although intercommune and interregional inequality in peasant income remained steady or even increased (Selden 1988; Zhang 1998). After the early 1980s, the peasant family was revived as an economic entity through decollectivization and family attributes again became relevant to a family's economic conditions (see the right-hand side of the figure).

With regard to the sociopolitical hierarchy (see the upper part of Figure 2), family class origin became a critical determinant of sociopolitical status throughout the Maoist era (Huang 1995; Unger 1982; Watson 1984; Zhang 1998). Family class origin was recorded with household registration, and as an implied political label, it influenced the rural population's education, employment, party membership, and all other social and economic opportunities. The pyramid-shaped sociopolitical hierarchy in the pre-1949 era became an inverse pyramid after the 1950s. Families labeled as landlord/rich peasant dropped to the bottom rung of the sociopolitical hierarchy as the 'bad' class, middle peasant families remained at the mid-level as the 'middle' class, and poor and lower-middle peasant families were at the top of the structure as the 'good' class (see the upper right-hand side of the figure). It was not until 1979 that the Communist Party announced the abolition of the class system as a measure of political accreditation. In every political campaign in the Maoist era, especially the Great Cultural Revolution, families of landlord and rich peasant origin were-in company with 'anti-revolutionaries', 'rogues', and 'right-wing factions'—included among the 'five blacks' (hei wulei) as the primary targets of an intense 'class struggle'. Opposing the 'five blacks' were the 'five reds' (hong wulei)—poor peasants, lower-middle peasants, workers, revolutionary soldiers, and revolutionary cadres—generally regarded as the primary basis of the socialist regime. 
Figure 2 about here

The 2002 CHIP survey provides information on the class origin of the heads of the household and their spouses’ parents. Based on this information, we adopt the following classification of family class origin.

(1) Families of landlord/rich peasant (dizhu/funong) origin. This is a family where either parent of the head of the household is of landlord/rich peasant origin.

(2) Families with poor and lower-middle peasant (pinxiazhongnong) origin. This is where both parents of the head of the household are of poor peasant or lower-middle peasant origin.

(3) Families of middle peasant (zhongnong) origin. This where both parents of the head of household are of middle peasant origin, or one of the parents is of middle peasant origin and the other is of a poor or lower-middle peasant origin. Rich middle peasants (fuyu zhongnong) and some other minor middle-class categories such as small landholders (xiao tudi chuzuzhe) and merchants (shangren) are classified as middle peasants.

In the overall working sample, families of landlord/rich peasant origin, middle peasant origin, and poor and lower-middle peasants’ origin comprise 6.0, 20.1, and 73.9 percent, respectively.

One possible criticism of the use of family class origin is that it is a crude indicator of family characteristics because the socioeconomic conditions of families designated as a certain class during the land reform (for example, landlords) vary considerably across regions. Our rationale for using family class origin is as follows. First, because family class origin became a fixed political label after the 1950s, its sociopolitical meaning is common to all areas. Second, although the economic substance of a certain class before the land reform 
varies between regions, it is reasonable to assume that class status represents relative socioeconomic status within each of the regional units where the land reform was implemented. If so, we can control the regional variation in the economic substance of a certain class by employing an appropriate regional dummy variable. In this manner, the county is the appropriate regional unit because it was the basic unit used for applying land reform policy. ${ }^{6}$

\section{Birth cohort}

The process of economic reform towards the market economy in China is roughly divided into two stages (Naughton 2007). The early stage of reform is the 1980s, characterized by the revival of market relations (and in rural areas, the decollectivization of agriculture and the development of Township and Village Enterprises or TVEs). The late stage of reform is the 1990s and after (more specifically, after 1992-1993 when the Chinese leadership accelerated reforms following the disruption of the Tiananmen Square incident in 1989). This period is characterized by the 'deepening' of marketization and includes the privatization of TVEs and the wave of rural-urban labor migration.

As illustrated in Table 1, to examine the differences in the role of family class origin in the different stages of economic reform, we divide the sample households into two cohorts according to the birth years of the household heads: an early-reform cohort and a late-reform cohort. The early-reform cohort consists of families with male heads of household born 19431954, who reached mature adult status (35 years old) during the early stage of economic reform (from the end of the 1970s to the late 1980s). The late-reform cohort consists of families with male heads of household born 1955-1967, who reached mature adult status during the late stage of economic reform (after the 1990s). Of the sample households in the working data set, the early-reform cohort accounts for 2,873 (45.3 percent) and the latereform cohort accounts for 3,466 (54.7 percent). 
Table 1 about here

\section{Data coverage and possible bias}

Here we discuss the coverage of our data. The sampling framework of the official household survey by the NBS is based on the hukou (household registration) system. Because the rural samples of the 2002 CHIP survey are sub samples of the NBS official household survey, our working data set is representative for the population holding rural hukou status, but it does not include those who had changed their hukou from a rural to an urban status (nongzhuanfei). If there was a considerable volume of permanent rural-urban migration by changing hukou status, and if we found a large difference in the probability of obtaining urban hukou status among people of different class origins, this could be a possible source of bias in our empirical analysis. However, we argue that the bias would not be serious for the following reasons.

First, the volume of permanent rural-urban migration with changing hukou status is very small. Based on the urban household data of the 2002 CHIP survey, we estimated that the ratio of rural-urban migration with changing hukou status was approximately 8 percent of the total population in 2002. This very low volume reflects the long-lasting strict restriction on rural-urban migration since the establishment of the hukou system at the end of the 1950s. Although the restriction of migration based on the hukou system has been relaxed in recent years, the massive inflow of rural populations into urban areas is still labor migration without changing the hukou status. Our family-based rural sample captures family members who outmigrated without changing their hukou status.

Second, although we found weak evidence of selective rural-urban migration based on family class origin, the magnitude and direction of the bias does not affect our discussion. Based on the 2002 CHIP urban survey, the ratio of former landlord/rich peasant family members to the total number of permanent migrants is 6.3 percent. This is almost the same as 
the percentage of former landlord/rich peasant families in our working data set. When we calculated the proportion of former landlord/rich peasant family members for different historical periods, we obtained the following figures: 5.2 percent for those who migrated during the period 1949-1979, 2.8 percent for those who migrated during the Great Cultural Revolution (1966-1975), and 7.6 percent for those who migrated after the 1980s. Although it is sometimes suggested that persons of 'bad' class origin were less likely to migrate during the Great Cultural Revolution, we did not find strong evidence of class origin-based selective migration during the entire Maoist era. This could be explained by the fact that in the Maoist era, and in addition to the selective traits for changing hukou status (such as becoming party/government cadres, entering college, and joining the army), there were also nonselective channels including expropriation of the village's cultivated land by the state.

\section{Class origin and family human capital}

Table 2 reports the association of family class origin with the relative wealth of the family. The figure in each cell is the ratio of the group mean (average wealth of families belonging to a certain class origin) to the grand mean wealth aggregated at the county level (county grand mean $=100$ ). This table shows interesting cohort differences. Regarding the early-reform cohort, the average wealth of middle peasant families is higher than the other classes. In the late-reform cohort, families of landlord/rich peasant origin become significantly richer. ${ }^{7}$ This suggests that we need to elaborate upon the association between class origin and family wealth. In the remainder of this section, and before estimating the family wealth function, we examine the association between family class origin and the current economic structure of the family and children/parental attributes.

Table 2 about here 
Table 3 reports the association between family class origin and offspring's human capital. Panels A and B in Table 3 clearly illustrate the legacy of class-based discrimination during the Maoist era. Using Panel A, we can see that the educational level of male heads of household with a landlord/rich peasant family background is relatively lower. Regarding the total of the two cohorts, the ratio of heads of household who received less than six years of schooling is 42.6 percent for former landlord/rich peasant families, 31.4 percent for middle peasant families, and 32.2 percent for poor and lower-middle peasant families. As shown in Panel B, similar class-based disparities are found with Communist Party membership. It should be noted that the association has become weaker for the late-reform cohort. This implies that the significance of class origin as a determinant of sociopolitical attainment has diminished. This is an expected outcome of the official abolition of class origin as a measure of political accreditation at the end of the 1970s.

Table 3 about here

In sum, we have found that differences in family wealth by class origin cannot be attributed to differences in family economic structure, and confirm that heads of household of landlord/rich peasant origin have an educational disadvantage because of class-based discrimination. ${ }^{8}$ It remains a puzzle that the economic status of families of landlord/rich peasant origin is higher than other families, in spite of the disadvantage in human capital formation. This seemingly contradictory finding urges us to consider human capital that cannot be accumulated through formal institutions (like schooling and political systems). Thus, we turn our attention to family human capital.

Table 4 summarizes the education and political attainment of the parents of current male heads of household. As expected, an opposing association to the case of current male heads of household is found with the level of education. Panels A and B in Table 4 illustrate that in the 
parents' generation, the level of education is highest for families of landlord/rich peasants origin and lowest for poor and lower-middle peasant families. Regarding the parents' political status, we find a similar association with male household heads (Panel C). The percentage of fathers with Communist Party membership is highest in poor and lower-middle peasant families and lowest in former landlord/rich peasant families. However, we do not see a significant association between mothers’ Party membership and family class origin because of the very low participation rate by women.

Panel D in Table 4 reports the occupational experiences of the family. Regarding to the early-reform cohort, and as expected, the proportion of families with nonagricultural family business experience before collectivization is lower among poor and lower-middle peasants than among their landlord/rich and middle peasant counterparts. For the late-reform cohort, since the majority of fathers of current heads of household had reached mature adult status (aged 35 years) after collectivization (see Table 1), there is no significant association between family class origin and parental family business experience. It should be noted that the interclass difference in parental family business experience is small, although it appears statistically significant for the early-reform cohort. This is mainly because nonagricultural activities were common in pre-revolution rural China and partly because we cannot control for the size of the business.

Table 4 about here

Summing up, these findings suggest that it is difficult to find a simple single association between measures of family human capital and family wealth. It is therefore necessary to proceed to the estimation of wealth functions that employ various human capital variables with additional controlling variables. 


\section{Intergenerational determinants of family wealth}

\section{Family wealth function}

The variables used in the family wealth function are described in Table 5. The dependent variable is the log of per capita family wealth in 2002. Family wealth is defined as the sum of financial assets, durable goods, housing assets, and fixed assets for production (the same definition as in Table 2). The explanatory variables comprise: (a) measures of family human capital, (b) measures of the human capital of male heads of household who are mature adults, (c) variables indicating family characteristics in 2002, and (d) an indicator of the level of regional economic development.

Table 5 about here

As described above, we employ the following measures of family human capital: (a-1) a dummy variable that indicates whether parent of male heads of household (or their spouses' parent) had any experiences of nonagricultural family businesses before collectivization (up to 1957); (a-2) dummy variables for family class origin (poor and lower-middle peasant status is specified as the reference category); (a-3) years of schooling completed by fathers of the male heads of household; (a-4) a dummy variable for Communist Party membership of the fathers of male heads of household. ${ }^{9}$ As for the human capital of the male heads of household, we use (b-1) years of education completed, and (b-2) a dummy variable for Communist Party membership. To control for the family’s demographic characteristics, we employ (c-1) the size of the contracted farmland allocated from the village, (c-2) the total number of family members and its square. We also introduce (c-3) the age of male heads of household and its square, or (c-4) the birth cohort of male heads of household (1 if early-reform cohort). Lastly, the county dummies are also employed as the control for regional variation in the 
classification of family class origin at the land reform period and other spatial socioeconomic factors.

Table 6 reports the estimation results. ${ }^{10}$ Equation 1 of Table 6 is a baseline estimation that includes only the main effects of family class origin and other variables for family human capital and other family characteristics. Equation 2 of Table 6 adds the interaction terms of family background and birth cohort of male heads of household.

Table 6 about here

From Table 6, we first find that neither of the two operational measures of parental human capital—formal schooling and Communist Party membership—have a statistically significant influence on family wealth. This implies that family human capital that cannot be measured by parental formalistic attributes matters.

\section{Family business experience before collectivization}

Table 6 shows that the parent's experience of nonagricultural family business is positively and significantly correlated with family wealth. If parents of male heads of household had any experiences in carrying on nonagricultural family business before collectivization, other factors remain the same; current family wealth will become approximately five percent higher than families without such experience (equation 1).

To examine whether this finding suggests the direct transmission of occupational experiences, Table 7 reports the association between male heads of household's occupational structure and parent's experience of nonagricultural family business by birth cohorts. Panel A of Table 7 shows that, regarding to the early-reform cohort, families whose parents had nonagricultural family business experience were more likely depending on nonagricultural family business in 2002 (the upper part of Panel A). This implies that the direct transmission of occupational experiences was important in the late Maoist era and the early stage of 
economic reform (the late 1970s and the 1980s) when physical and psychological barriers for entry into nonagricultural family business were high. However, the statistically significant association between parents' family business experience and current family income structure diminishes for the late-reform cohort (the lower part of Panel A). Panel B of the Table 7 suggests that parents' family business experience is also significantly associated with nonagricultural wage-oriented family income structure. It would appear that parental experience of nonagricultural family business influences offspring's attitude towards nonagricultural activities through cultural interaction with role model adults, rather than the direct transmission of specific occupational skills.

Table 7 about here

\section{Family class origin}

Table 6 also illustrates that after controlling parental education, political status, and occupational experience, family class origin still exerts a statistically significant influence on current family wealth. The offspring of landlord/rich and middle peasant backgrounds are likely to have greater family wealth than poor and lower-middle peasant families, even when other measures of family human capital and other individual/family attributes are controlled for. Equation 1 of Table 6 reports that the families of landlord/rich peasant origin and middle peasant origin have, other things being equal, approximately six percent higher per capita family wealth than former poor and lower-middle peasant families. The premium for middle peasant origin is almost the same as landlord/rich peasant origin. These class background premiums for family wealth are considerable when compared with the premium for individual human capital of male heads of household: approximately 13 percent for Communist Party membership and two percent for an additional year of schooling. 
Positive and statistically significant effects of landlord/rich peasant and middle peasant origin reinforce our inference that family class origin can be regarded as another substantive measure for the level of family human capital that has an independent influence on offspring's wealth. With the premise that well-off families before the revolution had richer stocks of family human capital stock, this suggests that although radical institutional change after 1949 thoroughly destroyed the physical capital stocks of well-off families, invisible family human capital was preserved throughout the Maoist era. This again began to play an important role after the revival of the family as the basic unit of economic activity.

Since we have already controlled for nonagricultural family business experience, the significant influence of family class origin implies that it represents an opportunity-oriented attitude towards economic activities and a general motivation for socioeconomic advancement. In other words, other individual, family, and regional conditions being equal, families with landlord/rich peasant and middle peasant origins are more likely to be entrepreneurial in a broader sense.

\section{Cohort lags in the influence of family human capital}

Using equation 2 in Table 6, which includes interaction terms of the family human capital variables with heads of household's birth cohort (early-reform cohort dummy); we have found a contrasting cohort difference in the effects of family background. The interaction term of landlord/rich peasant origin and the early-reform cohort dummy is negative and statistically significant, implying that the positive main effect of landlord/rich peasant origin becomes smaller through its negative interaction effect with the early-reform cohort. In the late-reform cohort, per capita family wealth of families of landlord/rich peasant origin is, other things being equal, 12.3 percent higher than poor and lower-middle peasant families. In the earlyreform cohort, this substantial gap is cancelled out by the large negative interaction effect with the early-reform cohort (13.1 percent). Concerning families of middle peasant origin, the 
interaction term with the early-reform cohort dummy is negative, but not statistically significant, suggesting that there is no significant cohort difference in the positive effect of middle class origin on family wealth.

We can better understand the cohort lag in the effect of family class origin between landlord/rich peasant families and middle peasant families with the following explanations. The first is the intrafamily social capital hypothesis. This hypothesis argues that the effectiveness of the intergenerational transmission of human capital depends on the level of parent (grandparent)-child interactions when children are in their adolescence and early adulthood (Coleman 1988; Meier 1999). The sociopolitical environment when offspring (in this case, current male heads of household) were in their adolescence and early adulthood varies considerably across the two historical cohorts. Those who belong to the early-reform cohort spent most of their adolescence during the 1960s and 1970s, and their sense of values is presumed to be strongly affected by the political atmosphere at the time. It would be reasonable to assume that the intergenerational transmission of family human capital was likely disrupted in families of landlord/rich peasant origin because their children would be reluctant to obediently listen to parents or grandparents labeled as persons of 'bad class'.

The negative and significant interaction effect of landlord/rich peasant origin and earlyreform cohort is considered to reflect the interrupted transmission of family human capital. In contrast to the preceding cohort, since the majority of heads of household with landlord/rich peasant origin who belong to the late-reform cohort spent their adolescence and early adulthood following the relaxation of political tensions in the mid-1970s, a relatively smooth transmission of family human capital within families of landlord/rich peasant origin is assumed. The positive main effect of landlord/rich peasant origin in equation 2 of Table 6 is supposed to reflect the resumption of the transmission of family human capital in the latereform cohort. 
The second explanation is that, due to class-based social discrimination, landlord/rich family members of the early-reform cohort faced obstacles in choosing lucrative job opportunities. If this is the case, landlord/rich family members could not exploit their human capital, even when there was a transmission of family human capital. In contrast to landlord/rich peasant families, the sociopolitical status of families of middle peasant origin was stable throughout the Maoist era. The significant positive main effect and insignificant interaction effect with birth cohort for middle peasant origin implies that there had been a relatively smooth transmission of family human capital in middle peasant families, who are considered to have relatively rich family human capital stock compared with poor and lowermiddle peasant families.

Unfortunately, since detailed life history data for sample households is not available, we cannot directly test the relevance of these explanations. Here we present indirect evidence that suggests that the socioeconomic attainments of landlord/rich peasant family members who belong to the early-reform cohort were subject to political limitations. First, as already shown in Panel B of Table 3, there is a statistically significant negative association between landlord/rich peasant status and Communist Party membership for male heads of household belonging to the early-reform cohort. Second, as reported in Table 8, male heads of household of landlord/rich peasant origin who belong to the early-reform cohort tend to be employed for longer hours in agricultural activities. Table 8 shows the determinants of labor allocation. The dependent variable is the number of working days of male heads of household allocated to agricultural activities (including forestry, livestock- and aqua-cultivating) in 2002. Explanatory variables include family background and individual attributes of male heads of household. Equation 1 of Table 8 illustrates that regarding to the early-reform cohort, male heads of household of landlord/rich peasant origin are employed for longer hours in agricultural activities. Concerning the late-reform cohort, no significant correlation is found 
between family class origin and employment structure (equation 2 of Table 8). This cohort difference can be understood as the aftereffect of an entry barrier for landlord/rich peasant family members of the early-reform cohort to access nonagricultural employment opportunities. ${ }^{11}$

Table 8 about here

\section{Level of economic development}

In contrast with family class origin, we have found no significant interaction effect between parental nonagricultural family business experience and heads of household's birth cohort (equation 2 of Table 6). It would be interesting to examine yet another interaction effect: that is, to what degree does the influence of the family background variables vary by the level of regional economic development. To investigate, Table 9 introduces GDP per capita at the county level and its interaction terms with the family human capital variables. ${ }^{12}$ The other controls are the same as Table 6.

Table 9 about here

Table 9 reports a negative and statistically significant interaction term of nonagricultural family business experience and per capita county GDP, showing that the positive effect of family business experience on family wealth decreases along with the overall level of regional economic development. This suggests that the experience or memory of nonagricultural activities transmitted from the pre-collectivization era appears to play the role of a stepping board for nonagricultural activities when the overall level of economic development is low.

In contrast to nonagricultural family business experience, the interaction terms of family class origin with per capita county GDP are insignificant. Although the signs are both negative showing a weak tendency for a decreasing influence on family wealth, the implication is that the effect of family class origin on offspring's family wealth is affected 
less by the level of regional economic development. In this sense, family class origin is a rather robust determinant of current family wealth.

\section{Conclusion}

We have considered the intergenerational transmission of family human capital and its influence on offspring's economic status in rural China. In summary, the estimation results suggest that family background, including parental occupational experience and class origin, rather than parental education or political status, have a significant influence on offspring's family wealth. This finding indicates the strength and robustness of the rural family.

By emphasizing the strength of the rural family, however, we do not intend to suggest that Chinese rural society displays a low level of fluidity. Conversely, as the discussed in the previous literature, rural society in the pre-Revolutionary era was rather instable and fluid. ${ }^{13}$ For example, according to his field survey in Xunwu County (Jiangxi Province) in 1930, Mao Zedong vividly illustrated that the majority of landlords in that region were 'small' landlords and that two-thirds were 'new rich' (xinfahuzi), whereas the remaining third were 'downfallen families' (poluohu) who had fallen from 'old big' landlords (Mao 1982/1941). ${ }^{14}$ According to Mao, the 'new rich', while originally ordinary peasants or petty merchants, were entrepreneurial families who had become rich through hard work. "Accumulating wealth is their principal motivation and working hard from early in the morning till late in the evening is their lifestyle” (Mao 1982/1941, 129). Family class origin can reflect such dynamic small entrepreneurship rather than a static stratified culture in pre-Revolutionary rural China.

It is noteworthy that recent studies on income mobility in post reform rural China also found high social fluidity. For example, using an intra-generational income mobility matrix between 1989-1997 based on the China Health and Nutrition Survey (CHNS), Wang (2005) ${ }^{15}$ argued that the overall level of family income mobility was higher in rural areas than in urban areas and that the relatively wealthy rural families were likely to experience downward 
mobility during the late 1980 s and the 1990 s. ${ }^{16}$ Therefore, our finding is that social fluidity in the pre-Revolutionary era interrupted by the socialist transformation surfaced again following economic reform. Those who inherited an opportunity-oriented family culture shaped in their parents’ generation were more likely to take an advantage of the early stage of market transition. However, if the high-income mobility in rural area continues, the influence of family characteristics inherited from the period before collectivization may diminish within a generation. We emphasize the robustness of the family here as a cultural entity that preserves family human capital against radical institutional transformations and politicoeconomic/ideological interventions by the state.

Due to data limitations, we concentrated on father-son inheritance and did not investigate the influence of lineage (zongzu) networks. One possible criticism of the father-son relationship (or family level in general) is that it could exaggerate the fluidity of rural society by ignoring the role of lineage networks standing against downward socioeconomic mobility. However, a recent study by Campbell and Lee argues that while some lineage groups were successful at transmitting prominent status over generations, the influence of successful senior kin members was generally too weak to guarantee success for junior kin members (Campbell and Lee 2003). Although further discussion of the role of kinship relations in socioeconomic mobility is left for future work, even if Campbell and Lee's argument is generally relevant to rural China then our conclusion would not be seriously affected by the omission of lineage networks.

In a more general setting, our study has some implications for comparative economic transition. It would be interesting to compare our findings with Szelényi’s 'interrupted embourgeoisement’ account of rural Hungary (Szelényi 1988). Szelényi, by utilizing extensive household survey data from rural Hungary at the beginning of the 1980s, compared economic outcomes between families of differential class origin. He found that the 'peasant 
entrepreneurs' who took advantage of the opening up of the market after the 1970s appeared to be the descendants of families who had been relatively well-off and entrepreneurial before the socialist transformation. According to Szelényi, the old rural bourgeoisie and middle classes could exploit the new market opportunities of the socialist mixed economy starting in the 1970s, not only by transmitting their family human capital through family education, but also by utilizing the educational system under the socialist regime. ${ }^{17}$ In rural China where thorough collectivization and radical political campaigns were undertaken, there were very few opportunities for formerly well-off families to preserve their family resources in the educational system (Sato and Li 2007). Here, the family human capital of formerly landlord/rich peasant families is mainly transmitted through within-family cultural interactions. In this sense, rural China differs considerably from the experience in rural Hungary. However, our findings and Szelényi's account share the view that in rural areas of transition economies, family human capital inherited from the pre-Revolutionary era matters in determining offspring's economic outcomes in the early stages of market transition. 


\section{References}

Bengtson, Vern, Biblarz, Timothy, and Roberts, Robert. 2002. How Families Still Matter: A Longitudinal Study of Youth in Two Generations. Cambridge: Cambridge University Press.

Bowles, Samuel, Gintis, Herbert, and Osborne-Groves, Melissa. 2005. Unequal Chances: Family Background and Economic Success. Princeton: Princeton University Press.

Caizhengbu Guokusi and Caizhengbu Yusuansi, eds. 2002. 2001 Nian Quanguo Di Shi Xian Caizheng Tongji Ziliao [Fiscal Statistics of Districts, Cities, and Counties], Beijing: Zhongguo Caizheng Jingji Chubanshe.

Campbell, Cameron and Lee, James. 2003. "Social mobility from a kinship perspective: rural Liaoning, 1789-1909.” International Review of Social History, 47:1-26.

Campbell, Cameron and Lee, James. 2006. "Kin networks, marriage and social mobility in Late Imperial China.” California Center for Population Research, On-Line Working Paper Series, CCPR-018-06, University of California - Los Angeles, pp. 1-42.

Coleman, James. 1988. "Social capital in the creation of human capital.” American Journal of Sociology, 94: Supplement, pp. S94-S120.

Crook, Isabel and Crook, David. 2003/1959. Revolution in a Chinese Village: Ten Mile Inn (International Library of Sociology). London: Routledge (reprint edition).

Deng, Zhong and Treiman, Donald. 1997. "The impact of the Cultural Revolution on trends in educational attainment in the People's Republic of China.” The American Journal of Sociology, 103:2, pp. 391-428.

Dunn, Thomas and Holtz-Eakin, Douglas. 2000. "Financial capital, human capital, and the transition to self-employment: evidence from intergenerational links.” Journal of Labor Economics. 18:2, pp. 282-305.

Erikson, Robert and Goldthorpe, John. 2002. "Intergenerational inequality: a sociological perspective.” Journal of Economic Perspectives, 16:3, pp. 31-44.

Fairlie, Robert and Alicia Robb. 2005. "Families, human capital, and small business: evidence from the characteristics of business owners survey." Center for Economic Studies, U.S. Census Bureau, Working Papers, pp. 1-28.

Fang, Hanming and Norman, Peter. 2006. "Government-mandated discriminatory policies: theory and evidence.” International Economic Review, 47:2, 361-389.

Gao, Wangling. 2006. Renmingongshe Shiqi Zhongguo Nongmin "Fanxingwei” Diaocha ["Non- and anti-collective" activities of Chinese Peasants during the People's Commune Era], Beijing: Zhonggong Danshi Chubanshe.

Grawe, Nathan and Mulligan, Casey. 2002. "Economic interpretations of intergenerational correlations.” Journal of Economic Perspectives, 16:3, pp. 45-48.

Guojia Ditu Bianji Weiyuanhui. 1989. Zhonghua Renmin Gongheguo Guojia Nongye Dituji [National Agricultural Atlas of the People’s Republic of China]. Beijing: Zhongguo Ditu Chubanshe.

Gustafsson, Björn, Li, Shi, and Sicular, Terry (eds.) 2008. Inequality and Public Policy in China. New York: Cambridge University Press. 
Harding, David, Jencks, Christopher, Lopoo, Leonard, and Mayer, Susan. 2005. "The changing effect of family background on the incomes of American adults", in Bowles, Samuel, Herbert Gintis, and Melissa Osborne-Groves eds., Unequal Chances: Family Background and Economic Success, Princeton: Princeton University Press, pp.100-144.

Khor, Niny, and Pencavel, John. 2006. "Income mobility of individuals in China and the United States.” Economics of Transition, 14: 3, pp.417-458.

Hinton, William. 1997/1967. Fanshen: A Documentary of Revolution in a Chinese Village. Berkeley: University of California Press (reprint edition).

Huang, Philip C. C. 1995. "Rural class struggle in the Chinese revolution: representational and objective realities from the Land Reform to the Cultural Revolution." Modern China, 21:1, pp. 105-143.

Mao, Zedong 1982/1941. "Xunwu diaocha [The Xunwu survey]," in Mao Zedong Nongcun Diaocha Wenji [Collection of Rural Surveys by Mao Zedong], Beijing: Renmin Chubanshe (originally published in 1941 as Nongcun Diaocha [Rural Suvey]).

Meier, Ann. 1999. "Social capital and social achievement among adolescents.” CDE Working Paper, 99-18.

Mincer, Jacob and Polachek, Solomon. 1974. "Family investments in human capital: earnings of women.” The Journal of Political Economy 82: 2 (Part 2: Marriage, Family Human Capital, and Fertility), pp. S76-S108.

Naughton, Barry. 2007. The Chinese Economy: Transition and Growth. Cambridge: The MIT Press.

Sato, Hiroshi and Li, Shi. 2007. "Class origin, family culture, and intergenerational correlation of education in rural China." IZA Discussion Paper Series

(Forschungsinstitut zur Zukunft der Arbeit, Institute for the Study of Labor), No. 2642, pp.1-41.

Selden, Mark. 1988. The Political Economy of Chinese Socialism. Armonk, New York: M.E. Sharpe.

Solon, Gary. 1992. “Intergenerational income mobility in the United States.” The American Economic Review, 82:3, pp. 393-408.

Szelényi, Ivan. 1988. Socialist Entrepreneurs: Embourgeoisement in Rural Hungary. Madison: University of Wisconsin Press.

Ting, Tih-Fen. 2004. "Resources, fertility, and parental investment in Mao’s China.” Population and Environment, 25:4, pp. 281-297.

Unger, Jonathan. 1982. Education under Mao. New York: Columbia University Press.

Wang, Haigang. 2005. “Zhongguo jumin jiating de shouru biandong ji qi dui changqi pingdeng de yingxing 1989-1997 [The household income mobility and its equalizing long-term income in China, 1989-1997].” Jingji Yanjiu, 2005: 1.

Watson, James ed. 1984. Class and Social Stratification in Post-Revolution China. Cambridge: Cambridge University Press.

Yin, Heng, Li, Shi, and Deng, Quheng. 2006. “Zhongguo chengzhen geren shouru liudongxing yanjiu [Mobility of personal income in urban China].” Jingji Yanjiu, 2006' 10, pp.30-43. 
Zhang, Letian. 1998. Gaobie Lixiang: Renmin Gongshe Zhidu Yanjiu [Farewell to the Idea: A Study of the People's Commune System]. Shanghai: Dongfang Chuban Zhongxin.

Zhang, Yongquan and Zhao, Quangou. 1985. Zhongguo Tudi Gaigeshi [History of the Land Reform in China]. Wuhan: Wuhan Daxue Chubanshe. 
Figure 1 Family class origin (chengfen)

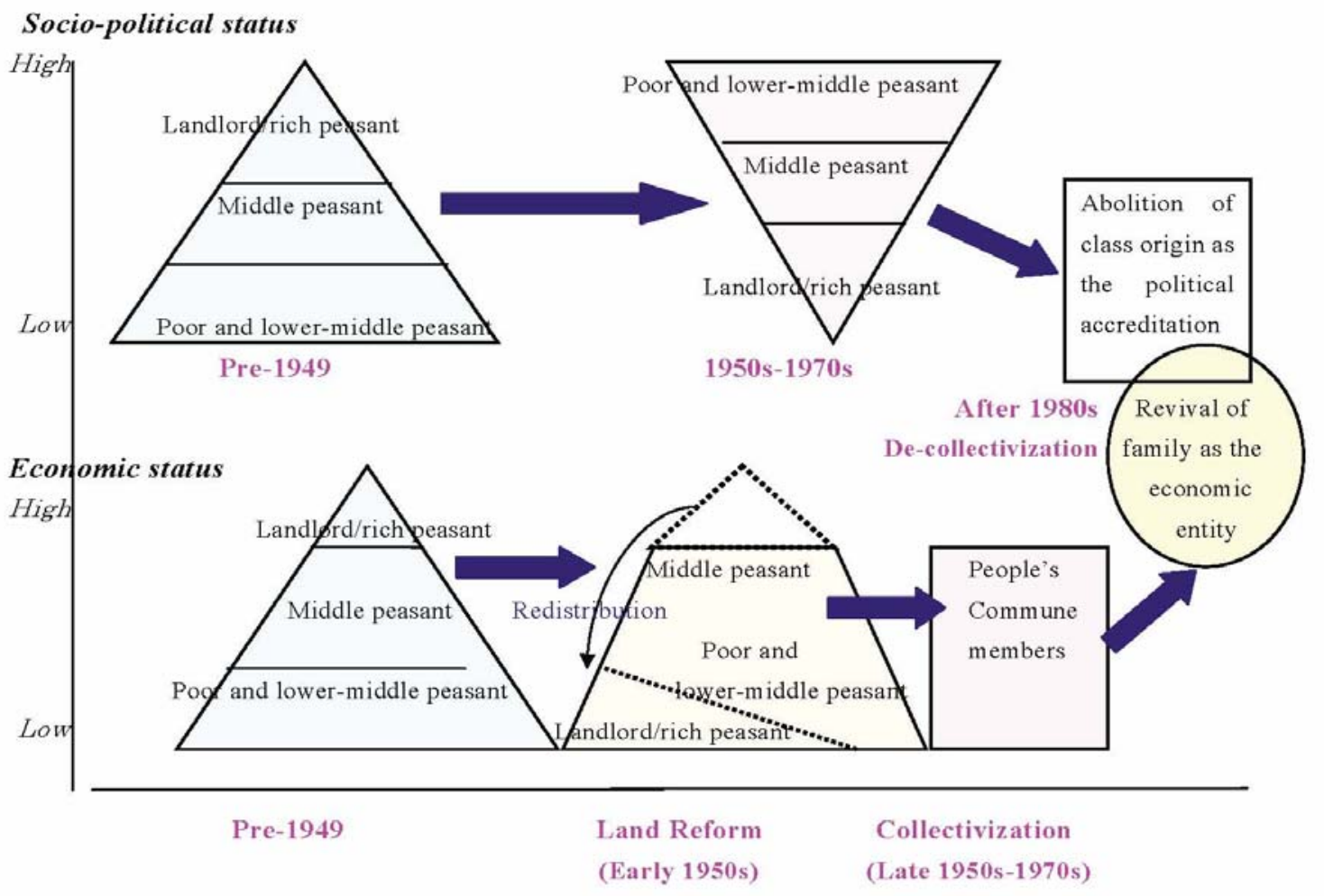


Table 1 Classification of historical cohorts

\begin{tabular}{|c|c|c|c|c|c|}
\hline $\begin{array}{l}\text { Birth year } \\
\text { (age in 2002) of } \\
\text { male heads of } \\
\text { household }\end{array}$ & $\begin{array}{l}\text { Period when in } \\
\text { adolescence } \\
\text { (Year of 15th } \\
\text { birthday) }\end{array}$ & $\begin{array}{l}\text { Period when } \\
\text { mature } \\
\text { adulthood } \\
\text { reached } \\
\text { (Year of 35th } \\
\text { birthday) }\end{array}$ & $\begin{array}{l}\text { Birth years of fathers } \\
\text { of male heads of } \\
\text { household } \\
\text { [Percentage of fathers } \\
\text { who had reached age } \\
35 \text { up to 1957] }\end{array}$ & $\begin{array}{l}\text { Historical events when male heads of } \\
\text { household were in their adolescence }\end{array}$ & $\begin{array}{l}\text { Number of } \\
\text { observations }\end{array}$ \\
\hline
\end{tabular}

\begin{tabular}{|c|c|c|c|c|c|}
\hline \multicolumn{6}{|l|}{ Early-reform cohort } \\
\hline \multicolumn{6}{|l|}{ Late-reform cohort } \\
\hline $\begin{array}{l}1955-1967 \\
(35-47)\end{array}$ & 1970-1982 & 1990-2002 & $\begin{array}{l}\text { Born in -1929: } 45 \% \\
\text { Born in 1930-: } 55 \% \\
{[18 \%]}\end{array}$ & $\begin{array}{l}\text { 1976: Destruction of the Gang of Four. } \\
\text { 1978: Third plenum of the 11th CPC } \\
\text { Central Committee. } \\
\text { 1979: Abolition of family class origin as an } \\
\text { indicator of political accreditation. } \\
\text { Early 1980s: Decollectivization. }\end{array}$ & $\begin{array}{c}3642 \\
(54.7 \%)\end{array}$ \\
\hline $\begin{array}{l}\text { Total number of } \\
\text { observations }\end{array}$ & & & & & $\begin{array}{c}6660 \\
(100.0 \%)\end{array}$ \\
\hline
\end{tabular}

Source: The data source for this and the following tables is the 2002 CHIP survey. 
Table 2 Relative wealth by class origin (ratio of class mean to grand mean aggregated at the county level)

\begin{tabular}{r|c|c|c|}
\hline \multicolumn{3}{c}{ Per capita family wealth in 2002 (county grand mean = 100) } \\
\cline { 2 - 4 } & $\begin{array}{l}\text { Landlord/rich } \\
\text { peasant }\end{array}$ & Middle peasant & $\begin{array}{l}\text { Poor and lower- } \\
\text { middle peasant }\end{array}$ \\
\hline $\begin{array}{c}\text { Cohort } \\
\text { Early-reform cohort }\end{array}$ & 97.7 & 108.2 & 99.6 \\
Late-reform cohort & $(197)$ & $(635)$ & $(2186)$ \\
$(3642)$ & $(208)$ & 102.0 & 97.2 \\
& & $(680)$ & $(2760)$ \\
\hline Total of both cohorts & 103.3 & 105.0 & 98.3 \\
$(6660)$ & $(399)$ & $(1315)$ & $(4946)$ \\
\hline
\end{tabular}

Notes: 1 . This table reports the relative wealth of families belonging to a certain class within the county where the sample households reside. Relative wealth is measured by the ratio of the group mean (average of per capita wealth of families belonging to a certain class origin) to the grand mean aggregated at the county level. Note that the county grand mean includes households with immature adult heads (younger than 35 years or older than 59 years).

2. Number of observations (households) in parenthesis. Family wealth is defined as the total value of financial assets, durable goods, housing assets, and fixed assets for production (at current prices). The number of observations in each cell (a certain class status and cohort) remains the same throughout Tables 3-5. 
Table 3 Class origin and offspring's human capital (schooling and political status of current male heads of household)

3A Schooling (\%)

\begin{tabular}{|c|c|c|c|c|}
\hline Cohort & $\begin{array}{l}\text { Landlord/rich } \\
\text { peasant }\end{array}$ & $\begin{array}{l}\text { Middle } \\
\text { peasant }\end{array}$ & $\begin{array}{l}\text { Poor and } \\
\text { lower-middle } \\
\text { peasant }\end{array}$ & Total \\
\hline \multicolumn{5}{|l|}{ Early-reform cohort } \\
\hline 4 years or less & 19.3 & 16.2 & 19.4 & 18.7 \\
\hline 5-6 years & 37.1 & 28.4 & 28.3 & 28.9 \\
\hline 7 years & 12.2 & 14.5 & 14.1 & 14.1 \\
\hline 8 years & 9.1 & 10.7 & 11.2 & 10.9 \\
\hline 9 years & 16.2 & 21.1 & 18.9 & 19.2 \\
\hline 10 years or more & 6.1 & 9.1 & 8.1 & 8.2 \\
\hline Total & 100.0 & 100.0 & 100.0 & $\begin{array}{l}100.0 \\
P=0.235\end{array}$ \\
\hline \multicolumn{5}{|l|}{ Late-reform cohort } \\
\hline 4 years or less & 11.4 & 5.6 & 7.0 & 7.0 \\
\hline 5-6 years & 18.3 & 14.7 & 15.4 & 15.4 \\
\hline 7 years & 11.4 & 15.4 & 15.5 & 15.2 \\
\hline 8 years & 18.8 & 20.7 & 22.2 & 21.8 \\
\hline 9 years & 20.3 & 26.8 & 23.2 & 23.7 \\
\hline 10 years or more & 19.8 & 16.8 & 16.8 & 17.0 \\
\hline Total & 100.0 & 100.0 & 100.0 & $\begin{array}{l}100.0 \\
P=0.067\end{array}$ \\
\hline \multicolumn{5}{|l|}{ Total of both cohorts } \\
\hline 4 years or less & 15.3 & 10.7 & 12.5 & 12.3 \\
\hline 5-6 years & 27.6 & 21.3 & 21.1 & 21.5 \\
\hline 7 years & 11.8 & 15.0 & 14.9 & 14.7 \\
\hline 8 years & 14.0 & 15.9 & 17.3 & 16.9 \\
\hline 9 years & 18.3 & 24.0 & 21.3 & 21.7 \\
\hline 10 years or more & 13.0 & 13.1 & 13.0 & 13.0 \\
\hline Total & 100.0 & 100.0 & 100.0 & $\begin{array}{l}100.0 \\
P=0.006\end{array}$ \\
\hline
\end{tabular}

3B Communist Party members (\%)

\begin{tabular}{|c|c|c|c|c|}
\hline Cohort & $\begin{array}{l}\text { Landlord/rich } \\
\text { peasant }\end{array}$ & Middle peasant & $\begin{array}{l}\text { Poor and lower- } \\
\text { middle peasant }\end{array}$ & Total \\
\hline $\begin{array}{l}\text { 1. Early-reform } \\
\text { cohort }\end{array}$ & 9.6 & 19.7 & 22.9 & $\begin{array}{c}21.3 \\
P=0.000\end{array}$ \\
\hline $\begin{array}{l}\text { 2. Late-reform } \\
\text { cohort }\end{array}$ & 11.9 & 14.7 & 16.5 & $\begin{array}{c}15.9 \\
P=0.138\end{array}$ \\
\hline $\begin{array}{l}\text { Total of both } \\
\text { cohorts }\end{array}$ & 10.8 & 17.1 & 19.3 & $\begin{array}{c}18.4 \\
P=0.000\end{array}$ \\
\hline
\end{tabular}

Note: $P$ denotes the significance level of the chi-square test of independence between family class origin and educational level, Communist Party membership. 
Table 4 Family human capital by class origin

4A Father's schooling (fathers of male heads of household, \%)

\begin{tabular}{|c|c|c|c|c|c|}
\hline Cohort & $\begin{array}{l}\text { Landlord/rich } \\
\text { peasant }\end{array}$ & $\begin{array}{l}\text { Middle } \\
\text { peasant }\end{array}$ & $\begin{array}{l}\text { Poor and lower- } \\
\text { middle peasant }\end{array}$ & Total & \\
\hline \multicolumn{6}{|c|}{ Early-reform cohort } \\
\hline No schooling & 24.4 & 40.6 & 48.7 & 45.4 & \\
\hline $1-3$ years & 30.0 & 26.5 & 30.3 & 29.5 & \\
\hline 4-6 years & 29.4 & 27.7 & 18.4 & 21.1 & \\
\hline 7 years or more & 16.2 & 5.2 & 2.6 & 4.0 & \\
\hline Total & 100.0 & 100.0 & 100.0 & 100.0 & $P=0.000$ \\
\hline \multicolumn{6}{|l|}{ Late-reform cohort } \\
\hline No schooling & 19.3 & 31.6 & 38.2 & 35.9 & \\
\hline $1-3$ years & 22.7 & 26.6 & 31.1 & 29.8 & \\
\hline 4-6 years & 36.6 & 29.3 & 24.9 & 26.4 & \\
\hline 7 years or more & 21.3 & 12.5 & 5.8 & 7.9 & \\
\hline Total & 100.0 & 100.0 & 100.0 & 100.0 & $P=0.000$ \\
\hline
\end{tabular}

4B Mother's schooling (mothers of male heads of household, \%)

\begin{tabular}{|c|c|c|c|c|}
\hline Cohort & $\begin{array}{l}\text { Landlord/rich } \\
\text { peasant }\end{array}$ & $\begin{array}{l}\text { Middle } \\
\text { peasant }\end{array}$ & $\begin{array}{l}\text { Poor and lower- } \\
\text { middle peasant }\end{array}$ & Total \\
\hline \multicolumn{5}{|c|}{ Early-reform cohort } \\
\hline No schooling & 77.2 & 80.1 & 80.1 & 79.9 \\
\hline $1-3$ years & 14.7 & 16.5 & 16.7 & 16.5 \\
\hline 4-6 years & 6.6 & 3.2 & 3.2 & 3.4 \\
\hline 7 years or more & 1.5 & 0.3 & 0.1 & 0.3 \\
\hline Total & 100.0 & 100.0 & 100.0 & $100.0 P=0.000$ \\
\hline \multicolumn{5}{|l|}{ Late-reform cohort } \\
\hline No schooling & 53.5 & 66.6 & 69.9 & 68.3 \\
\hline $1-3$ years & 24.8 & 21.0 & 20.8 & 21.0 \\
\hline 4-6 years & 17.8 & 9.4 & 8.4 & 9.1 \\
\hline 7 years or more & 4.0 & 2.9 & 1.0 & 1.5 \\
\hline Total & 100.0 & 100.0 & 100.0 & $100.0 P=0.003$ \\
\hline
\end{tabular}


Table 4 continued

4C Parent's Communist Party membership ( \%)

\begin{tabular}{|c|c|c|c|c|}
\hline Cohort & $\begin{array}{l}\text { Landlord/rich } \\
\text { peasant }\end{array}$ & Middle peasant & $\begin{array}{l}\text { Poor and lower- } \\
\text { middle peasant }\end{array}$ & Total \\
\hline \multicolumn{5}{|l|}{ Father } \\
\hline $\begin{array}{l}\text { Early-reform } \\
\text { cohort } \\
\text { Late-reform } \\
\text { cohort }\end{array}$ & $\begin{array}{l}2.5 \\
5.0\end{array}$ & $\begin{array}{r}4.9 \\
13.4\end{array}$ & $\begin{array}{r}8.5 \\
15.5\end{array}$ & $\begin{array}{c}7.3 \\
P=0.000 \\
14.5 \\
P=0.000\end{array}$ \\
\hline \multicolumn{5}{|l|}{ Mother } \\
\hline $\begin{array}{l}\text { Early-reform } \\
\text { cohort }\end{array}$ & 0.5 & 0.3 & 0.8 & $\begin{array}{c}0.7 \\
P=0.377\end{array}$ \\
\hline Late-reform & 1.0 & 0.6 & 1.5 & $\begin{array}{c}1.3 \\
P=0.147\end{array}$ \\
\hline
\end{tabular}

4D Parents having experience of nonagricultural family business before collectivization (up to 1957) (\%)

\begin{tabular}{l|c|l|l|l}
\hline Cohort & $\begin{array}{l}\text { Landlord/rich } \\
\text { peasant }\end{array}$ & Middle peasant & $\begin{array}{l}\text { Poor and lower- } \\
\text { middle peasant }\end{array}$ & Total \\
\hline $\begin{array}{l}\text { Early-reform } \\
\text { cohort }\end{array}$ & 14.2 & 13.1 & 8.2 & 9.6 \\
$\begin{array}{l}\text { Late-reform } \\
\text { cohort }\end{array}$ & 7.4 & 10.9 & 7.5 & $\begin{array}{c}8.2 \\
P=0.000\end{array}$ \\
\hline
\end{tabular}

Note: $P$ denotes the significance level of the chi-square test of independence between family class origin and the relevant variables. 
Table 5 Description of variables for family wealth functions

\begin{tabular}{|c|c|}
\hline Variables & Description \\
\hline $\begin{array}{l}\text { Dependent variable } \\
\text { Log of per capita family wealth in } 2002\end{array}$ & $\begin{array}{l}\text { Log of per capita amount of family wealth in } 2002 \\
\text { including total value of financial assets, durable } \\
\text { goods, housing assets, and fixed assets for } \\
\text { production }\end{array}$ \\
\hline \multicolumn{2}{|l|}{$\begin{array}{l}\text { Explanatory variables } \\
\text { (a) Family human capital }\end{array}$} \\
\hline $\begin{array}{l}\text { (a-1) Parents' experience of } \\
\text { nonagricultural family business before } \\
\text { collectivization }\end{array}$ & $\begin{array}{l}1 \text { if parents and/or parents-in-law of male heads of } \\
\text { household were age } 20 \text { or over in } 1957 \text { and had any } \\
\text { nonagricultural family businesses, otherwise } 0\end{array}$ \\
\hline (a-2) Family class origin & $\begin{array}{l}\text { Dummy variables for family class origin } \\
\text { (landlord/rich peasant; middle peasant; poor and } \\
\text { lower-middle peasant) }\end{array}$ \\
\hline (a-3) Father's years of schooling & $\begin{array}{l}\text { Years of schooling completed by fathers of male } \\
\text { heads of household }\end{array}$ \\
\hline $\begin{array}{l}\text { (a-4) Father's Communist Party } \\
\text { membership }\end{array}$ & $\begin{array}{l}1 \text { if fathers of male heads of household having } \\
\text { Communist Party membership, otherwise } 0\end{array}$ \\
\hline \multicolumn{2}{|c|}{ (b) Human capital of male heads of household } \\
\hline (b-1) Years of schooling & $\begin{array}{l}\text { Years of education completed by male heads of } \\
\text { household }\end{array}$ \\
\hline (b-2) Communist Party membership & $\begin{array}{l}1 \text { if male heads of household having Communist } \\
\text { Party membership, otherwise } 0\end{array}$ \\
\hline \multicolumn{2}{|l|}{ (c) Current family characteristics } \\
\hline (c-1) Size of contracted farmland & $\begin{array}{l}\text { Per capita contracted farmland in } 2002 \text { in mu (one } \\
\mathrm{mu}=0.067 \text { hectare) }\end{array}$ \\
\hline (c-2) Household size & Total number of family members, 2002 \\
\hline (c-3) Age of heads of household & $\begin{array}{l}\text { Age of male heads of household in } 2002 \text { and its } \\
\text { square term }\end{array}$ \\
\hline (c-4) Birth cohort of head of household & $\begin{array}{l}1 \text { if male head of household belongs to the early- } \\
\text { reform cohort, otherwise } 0\end{array}$ \\
\hline
\end{tabular}


Table 6 Family wealth function (OLS estimation)

\begin{tabular}{|c|c|c|}
\hline Dependent variable: Log of per capita family wealth, 2002 & (1) Baseline & $\begin{array}{l}\text { (2) With inter- } \\
\text { action term } \\
\text { with birth } \\
\text { cohort }\end{array}$ \\
\hline \multicolumn{3}{|l|}{ Explanatory variables } \\
\hline \multicolumn{3}{|l|}{ Family human capital } \\
\hline $\begin{array}{l}\text { (a-1) Parents' experience of nonagricultural family business } \\
\text { before collectivization }\end{array}$ & $\begin{array}{l}0.052 \\
(1.85)^{*}\end{array}$ & $\begin{array}{l}0.028 \\
(0.73)\end{array}$ \\
\hline (a-2) Landlord/rich peasant origin & $\begin{array}{l}0.059 \\
(1.75)^{*}\end{array}$ & $\begin{array}{l}0.123 \\
(2.64)^{* * *}\end{array}$ \\
\hline Middle peasant origin & $\begin{array}{l}0.058 \\
(2.87)^{* * *}\end{array}$ & $\begin{array}{l}0.076 \\
(2.76)^{* * *}\end{array}$ \\
\hline (a-3) Father's years of schooling & $\begin{array}{l}0.001 \\
(0.32)\end{array}$ & $\begin{array}{l}0.0004 \\
(0.09)\end{array}$ \\
\hline (a-4) Father’s Communist Party membership & $\begin{array}{l}0.015 \\
(0.58)\end{array}$ & $\begin{array}{l}0.018 \\
(0.70)\end{array}$ \\
\hline \multicolumn{3}{|l|}{ Human capital of male heads of household } \\
\hline (b-1) Years of education completed & $\begin{array}{l}0.021 \\
(5.96)^{* * *}\end{array}$ & $\begin{array}{l}0.021 \\
(5.98)^{* * *}\end{array}$ \\
\hline (b-2) Communist Party membership & $\begin{array}{l}0.133 \\
(6.38) * * *\end{array}$ & $\begin{array}{l}0.132 \\
(6.33) * * *\end{array}$ \\
\hline \multicolumn{3}{|l|}{ Family characteristics } \\
\hline (c-1) Per capita contracted farmland & $\begin{array}{l}0.010 \\
(1.77)^{*}\end{array}$ & $\begin{array}{l}0.010 \\
(1.85)^{*}\end{array}$ \\
\hline (c-2) Household size & $\begin{array}{l}-0.316 \\
(10.36)^{* * *}\end{array}$ & $\begin{array}{l}-0.308 \\
(10.24)^{* * *}\end{array}$ \\
\hline Household size squared & $\begin{array}{l}0.019 \\
(6.00)^{* * *}\end{array}$ & $\begin{array}{l}0.019 \\
(5.86)^{* * *}\end{array}$ \\
\hline (c-3) Age of head of household & $\begin{array}{l}0.045 \\
(2.70) * * *\end{array}$ & \\
\hline Age of head of household (squared) & $\begin{array}{l}-0.0005 \\
(2.54)^{* *}\end{array}$ & \\
\hline $\begin{array}{l}\text { (c-4) Head of household belonging to the early-reform } \\
\text { cohort }\end{array}$ & & $\begin{array}{l}0.046 \\
(2.35)^{* *}\end{array}$ \\
\hline
\end{tabular}


Table 6 continued

Interaction terms of family human capital and birth cohort

Landlord/rich peasant $\times$ Early-reform cohort $\quad-0.131$

$(2.00)^{* *}$

Middle peasant $\times$ Early-reform cohort $\quad-0.038$

(0.96)

Nonagricultural family business $\times$ Early-reform cohort

0.054

(0.99)

Regional dummies (County)

YES

YES

Constant

9.167

10.236

$(23.08)^{* *}$

$(93.29)^{* * *}$

Number of observations

6660

6660

Adjusted R-squared

0.486

0.487

Note: Absolute values of t-statistics in parenthesis. ${ }^{* * *}$ Denotes statistical significance at the $1 \%$ level, ** at the $5 \%$ level, * at the $10 \%$ level. 
Table 7 Association between parent's family business experience and current male heads of household's family income structure

7A Nonagricultural family business (\%)

\begin{tabular}{l|c|c|c}
\hline \multirow{2}{*}{$\begin{array}{l}\text { Whether income from nonagri- } \\
\begin{array}{l}\text { cultural family business is higher } \\
\text { agricultural income }\end{array}\end{array}$} & \multicolumn{2}{|c}{$\begin{array}{c}\text { Whether parents had experience of nonagricultural } \\
\text { family business before collectivization }\end{array}$} \\
\cline { 2 - 4 } & Having & Not having & Total \\
\hline Early-reform cohort & 14.1 & 10.5 & 10.8 \\
\hline Yes & 85.9 & 89.5 & 89.2 \\
\hline No & 100.0 & 100.0 & 100.0 \\
\hline Total & $(290)$ & $(2728)$ & $P=0.057$ \\
\hline Late-reform cohort & 15.4 & 16.5 & 15.5 \\
\hline Yes & 84.6 & 83.5 & 84.5 \\
\hline No & 100.0 & 100.0 & 100.0 \\
\hline Total & $(297)$ & $(3345)$ & $P=0.615$ \\
\hline
\end{tabular}

7B Nonagricultural wage employment (\%)

\begin{tabular}{l|c|c|c}
\hline \multirow{2}{*}{$\begin{array}{l}\text { Whether nonagricultural wage } \\
\begin{array}{l}\text { income is higher agricultural } \\
\text { income }\end{array}\end{array}$} & \multicolumn{2}{|c}{$\begin{array}{l}\text { Whether parents had experience of nonagricultural } \\
\text { family business before collectivization }\end{array}$} \\
\cline { 2 - 4 } & Having & Not having & Total \\
\hline Early-reform cohort & 48.3 & 37.5 & 38.5 \\
\hline Yes & 51.7 & 62.5 & 61.5 \\
\hline No & 100.0 & 100.0 & 100.0 \\
\hline Total & $(290)$ & $(2728)$ & $P=0.000$ \\
\hline Late-reform cohort & & & 37.2 \\
\hline Yes & 45.8 & 36.4 & 62.8 \\
\hline No & 54.2 & 63.6 & 100.0 \\
\hline Total & 100.0 & 100.0 & $P=0.001$ \\
\hline
\end{tabular}

Notes: 1. Number of observations (households) in parenthesis.

2. $P$ denotes the significance level of the chi-square test of independence between parent's family business experience and offspring's family income structure 
Table 8 Family class origin and number of working days for agricultural activities (OLS estimation)

Dependent variable: Number of working days of male heads of household allocated to agricultural activities in 2002 (including forestry, livestock- and aqua-cultivating)

\section{Explanatory variables

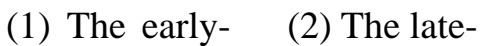 reform cohort reform cohort}

\begin{tabular}{lll}
\hline Family background & & \\
\hline (a-1) Parents' experience of nonagricultural family business & -15.633 & -3.471 \\
before collectivization & $(3.30)^{* * *}$ & $(0.74)$ \\
& 14.281 & 2.404 \\
(a-2) Landlord/rich peasant origin & $(2.51)^{* *}$ & $(0.43)$ \\
& 3.048 & -0.114 \\
Middle peasant origin & $(0.87)$ & $(0.03)$
\end{tabular}

\begin{tabular}{lll}
\hline Characteristics of male heads of household family & & \\
\hline Years of education of male heads of household & -1.190 & -3.243 \\
& $(2.01)^{* *}$ & $(5.44)^{* * *}$ \\
Communist Party membership of male heads of household & -8.431 & -5.134 \\
& $(2.47)^{* *}$ & $(1.43)$ \\
\hline Per capita contracted farmland & 6.044 & 5.890 \\
& $(5.01)^{* * *}$ & $(7.25)^{* * *}$ \\
Household size & 12.714 & 12.002 \\
& $(2.97)^{* * *}$ & $(1.78)^{*}$ \\
Household size squared & -0.966 & -0.865 \\
& $(2.15)^{* *}$ & $(1.23)$ \\
& & \\
\hline Regional dummies (County) & YES & YES \\
Constant & -8.960 & 6.927 \\
& $(0.52)$ & $(0.34)$ \\
\hline Number of observations & & 3618 \\
\hline
\end{tabular}

Note: Absolute values of t-statistics in parenthesis. *** Denotes statistical significance at the $1 \%$ level, ** at the $5 \%$ level, * at the $10 \%$ level. 
Table 9 Family wealth function with interaction terms of regional income and family human capital

Dependent variable: Log of per capita family wealth, 2002

\section{Explanatory variables}

Family human capital

(a-1) Experience of nonagricultural family

business before collectivization

0.189

(a-2) Landlord/rich peasant origin

$(3.93)^{* * *}$

Middle peasant origin

$(2.21)^{* *}$

(a-3) Father’s years of schooling

$-0.001$

(a-4) Father’s Party membership

$(0.08)$

\section{Regional income its interaction terms with family human capital}

Experience of nonagricultural family business

$-0.015$

$\times$ GDP per capita at the county level

Landlord/rich peasant $\times$ GDP per capita at the county level

Middle peasant $\times$ GDP per capita at the county level

$-0.006$

GDP per capita at the county level

0.074

$(29.60)^{* * *}$

Human capital of male heads of household

YES

Family characteristics

YES

Regional dummies (Province)

YES

Number of observations 6660

Adjusted R-squared 0.387

Notes: 1. Variables in equation (1) in Table 7 are included in the estimation but not reported. Absolute values of t-statistics in parenthesis.

2. Per capita GDP at the county level for 2001 (in thousands of yuan) compiled from Caizhengbu Guokusi and Caizhengbu Yusuansi (2002).

3. *** Denotes statistical significance at the $1 \%$ level, ** at the $5 \%$ level, * at the $10 \%$ level. 
Appendix: Descriptive statistics of variables in the family wealth function

\begin{tabular}{|c|c|c|c|}
\hline & $\begin{array}{l}\text { (1) Total of both } \\
\text { cohorts }\end{array}$ & $\begin{array}{l}\text { (2) Early- } \\
\text { reform cohort }\end{array}$ & $\begin{array}{l}\text { (3) Late-reform } \\
\text { cohort }\end{array}$ \\
\hline Per capita family wealth, 2002 (yuan) & $\begin{array}{l}10324.38 \\
(12333.72)\end{array}$ & $\begin{array}{l}10681.43 \\
(12717.12)\end{array}$ & $\begin{array}{l}10028.51 \\
(12000.45)\end{array}$ \\
\hline Log of per capita family wealth, 2002 & $\begin{array}{l}8.852 \\
(0.870)\end{array}$ & $\begin{array}{l}8.890 \\
(0.864)\end{array}$ & $\begin{array}{l}8.820 \\
(0.875)\end{array}$ \\
\hline Age of head of household & $\begin{array}{l}46.354 \\
(6.765)\end{array}$ & $\begin{array}{l}52.675 \\
(3.289)\end{array}$ & $\begin{array}{l}41.117 \\
(3.765)\end{array}$ \\
\hline Landlord/rich peasant origin & $\begin{array}{l}0.060 \\
(0.237)\end{array}$ & $\begin{array}{l}0.065 \\
(0.247)\end{array}$ & $\begin{array}{l}0.055 \\
(0.229)\end{array}$ \\
\hline Middle peasant origin & $\begin{array}{l}0.197 \\
(0.398)\end{array}$ & $\begin{array}{l}0.210 \\
(0.408)\end{array}$ & $\begin{array}{l}0.187 \\
(0.390)\end{array}$ \\
\hline Father's years of schooling & $\begin{array}{l}3.959 \\
(1.793)\end{array}$ & $\begin{array}{l}3.774 \\
(1.574)\end{array}$ & $\begin{array}{l}4.113 \\
(1.942)\end{array}$ \\
\hline Father's Party membership & $\begin{array}{l}0.112 \\
(0.316)\end{array}$ & $\begin{array}{l}0.073 \\
(0.261)\end{array}$ & $\begin{array}{l}0.145 \\
(0.352)\end{array}$ \\
\hline $\begin{array}{l}\text { Parents' experience of nonagricultural } \\
\text { family business before collectivization }\end{array}$ & $\begin{array}{l}0.088 \\
(0.284)\end{array}$ & $\begin{array}{l}0.096 \\
(0.295)\end{array}$ & $\begin{array}{l}0.082 \\
(0.274)\end{array}$ \\
\hline Years of education completed & $\begin{array}{l}7.299 \\
(2.484)\end{array}$ & $\begin{array}{l}6.630 \\
(2.554)\end{array}$ & $\begin{array}{l}7.853 \\
(2.280)\end{array}$ \\
\hline Communist Party membership & $\begin{array}{l}0.184 \\
(0.387)\end{array}$ & $\begin{array}{l}0.213 \\
(0.410)\end{array}$ & $\begin{array}{l}0.159 \\
(0.366)\end{array}$ \\
\hline Per capita farmland (mu) & $\begin{array}{l}1.447 \\
(1.891)\end{array}$ & $\begin{array}{l}1.428 \\
(1.686)\end{array}$ & $\begin{array}{r}1.463 \\
(2.046)\end{array}$ \\
\hline Household size & $\begin{array}{l}4.227 \\
(1.240)\end{array}$ & $\begin{array}{l}4.214 \\
(1.454)\end{array}$ & $\begin{array}{l}4.238 \\
(1.030)\end{array}$ \\
\hline Age of heads of household & $\begin{array}{l}46.354 \\
(6.765)\end{array}$ & $\begin{array}{l}52.675 \\
(3.289)\end{array}$ & $\begin{array}{l}41.117 \\
(3.765)\end{array}$ \\
\hline $\begin{array}{l}\text { Head of household belonging to the } \\
\text { early-reform cohort }\end{array}$ & $\begin{array}{l}0.453 \\
(0.498)\end{array}$ & & \\
\hline $\begin{array}{l}\text { GDP per capita at the county level } \\
\text { (thousand yuan) }\end{array}$ & $\begin{array}{l}6.284 \\
(5.015)\end{array}$ & & \\
\hline Number of observations & 6660 & 3018 & 3642 \\
\hline
\end{tabular}

Note: This table reports the mean and standard deviation of each of the variables used in the family wealth function. Standard deviations are in parenthesis. 
${ }^{1}$ The CHIP survey was administered in 1988 and 1995 using a similar sampling framework and questionnaires. However, these rounds of the survey did not include information on family class origin. For details of the sampling framework and sampling method of the CHIP 2002 survey, see Gustafsson, Li, and Sicular (2008).

${ }^{2}$ For the notion of family and family human capital, see Bengtson et al. (2002), Bowles et al. (2005), Coleman (1988), Erikson and Goldthorpe (2002), Grawe and Mulligan (2002), Mincer and Polachek (1974), and Solon (1992).

${ }^{3}$ Educational and cultural goods available at home can also be a component of family human capital. Because most of these goods in well-off families were lost with the land reform, we do not consider them in our research.

${ }^{4}$ We do not mean that private economic activities vanished altogether under the People's Commune system. Recognized and unrecognized private activities, including commerce and manufacturing, constituted an indispensable part of peasant income during the Maoist era (see, for example, Zhang 1998, Gao 2006).

${ }^{5}$ One common finding of the extant literature on self-employment is that a parent's experience of self-employment positively affects the probability of entering selfemployment during the offspring's generation (see, for example, the case of the United States discussed in Dunn and Holtz-Eakin 2000 and Fairlie and Robb 2005).

${ }^{6}$ For example, a typical method for supervising the land distribution process was to dispatch work teams (gongzuodui) organized at the county level to villages (Crook and Crook 2003/1959; Hinton 1997/1967).

${ }^{7}$ While not reported in the table, similar associations are found when we use the five-year (1998-2002) average of per capita family income.

${ }^{8}$ See our previous paper (Sato and Li 2007) for a detailed discussion of the influence of class-based discrimination in education during the Maoist era.

${ }^{9}$ The literature on the intergenerational correlation of human capital generally uses the educational attainments of both the father and mother. We estimated the family wealth function, including the mother's educational level and political attainment, and confirmed that the mother's attributes do not have a statistically significant effect. For simplification, we do not include mothers' attributes in the discussion.

${ }^{10}$ As an alternative to the family wealth function, we also estimated the family income function using the five-year (1998-2002) average of per capita family income. The estimated outcomes are consistent with the family wealth function reported in Table 7 and we can elicit similar conclusions.

11 Though not reported in the table, we have also confirmed that there is no statistically significant association between family class origin and income structure for 2002 of families belonging to the late-reform cohort. The proportion of families where nonagricultural wage income exceeds agricultural income in 2002 are 33.2 percent for landlord/rich peasant families, 36.0 percent for middle peasant families, and 37.8 percent for poor and lower-middle peasant families respectively (the significance level of the chisquare test of independence between family class origin and income structure is 0.330). Similarly, proportions of families where earnings from nonagricultural family business is higher than agricultural income are 15.8 percent for landlord/rich peasant families, 17.7 percent for middle peasant families, and 14.9 percent for poor and lower-middle peasant families respectively (the significance level of the chi-square test is 0.212).

${ }^{12}$ County GDP is compiled from Caizhengbu Guokusi and Caizhengbu Yusuansi (2002). 
${ }^{13}$ A complicated mixture of various factors such as marketization and globalization of rural economy, political instability and civil wars, as well as the traditional divided (equal) inheritance system are considered the source of social fluidity in pre-Revolutionary rural China.

${ }^{14}$ Mao reported the share of each class in overall rural population of Xunwu County as follows: 'big and middle' landlord is one percent; 'small' landlord, three percent; rich peasant, four percent; middle peasant, 18 percent, poor peasant, 70 percent; worker three percent; other poor population one percent (Mao 1941/1982, 105).

15 The China Health and Nutrition Survey is an ongoing household panel survey conducted by the Carolina Population Center at the University of North Carolina at Chapel Hill, the National Institute of Nutrition and Food Safety, and the Chinese Center for Disease Control and Prevention (http://www.cpc.unc.edu/projects/china).

${ }^{16}$ Regarding urban China, previous work has revealed that household income mobility in the former half of the 1990s was higher than the US and other developed economies (Khor and Pencavel 2006) but the level of mobility apparently decreased in the latter half of the 1990s (Yin, Li, and Deng 2006). According to Wang (2005), the level of income mobility in rural areas remained high in the late 1990s.

${ }^{17}$ In rural Hungary, many 'kulak' descendants who entered their adult lives after the mid1950s could get into middle school and become highly qualified technicians (Szelényi 1988, 171-179). 